\title{
Employer branding: estudo de caso em uma multinacional farmacêutica
}

\section{Employer branding: case study in a multinational pharmaceutical}

\author{
Julia Shirazawa Gaspar Graduação em Administração. Universidade Federal de São Paulo (UNIFESP)- Brasil. \\ https://orcid.org/0000-0002-8861-0430 juliashirazawagaspar@gmail.com \\ Taís Pasquotto Andreoli Doutorado em Administração (USCS). Professora Universidade Federal de São Paulo (UNIFESP)- \\ https://orcid.org/0000-0002-9173-9294 Brasil.tais.andreoli@unifesp.br
}

\begin{abstract}
RESUMO
O estudo teve como objetivo analisar a compreensão e utilização do Employer Branding em uma organização multinacional do ramo farmacêutico. Para isso, procedeu-se, inicialmente, a uma revisão de literatura com foco na discussão acerca do tema de marca empregadora, sua importância, aplicação e desafios. Tendo a literatura como suporte, este trabalho adotou metodologicamente a abordagem qualitativa, de natureza descritiva, realizado por meio de um estudo de caso, selecionando-se uma organização multinacional do ramo farmacêutico. A triangulação foi conseguida por meio da análise de dados secundários para a apresentação e caracterização da empresa escolhida, amparada na observação participante e levantamento de dados primários com a aplicação de entrevistas semiestruturadas junto a quatro gestores. Com isso, foi possível verificar que tanto as estratégias da marca empregadora são aplicadas na empresa, quanto, mais importante, como são percebidas pelos seus colaboradores, tanto de maneira implícita quanto explicitamente. Como resultado, foi possível observar que a gestão de marca empregadora impacta diretamente na visibilidade de uma marca e empresa perante o público, sendo crucial para a atração de talentos, bem como, na satisfação, engajamento e retenção dos colaboradores em uma organização.
\end{abstract}

Palavras-chave: Employer Branding. Gestão de Marca Empregadora. Diferencial competitivo. Estudo de caso.

\section{ABSTRACT}

The study aimed to analyze the understanding and use of Employer Branding in a multinational organization in the pharmaceutical industry. To this end, a review of the literature was carried out, with focus on the discussion on the topic of the employing brand, its importance, application and challenges. Having the literature as support, this work methodologically adopted the qualitative approach, of a descriptive nature, carried out through a case study, selecting a multinational organization in the pharmaceutical field. The triangulation was achieved through the analysis of secondary data for the presentation and characterization of the chosen company, supported by the participant observation and survey of primary data with the application of semi-structured interviews with four managers. Thus, it was possible to verify that both the strategies of the employing brand are applied in the company, and, more importantly, how they are perceived by its employees, both implicitly and explicitly. As result, it was possible to observe that employer brand management directly impacts the visibility of a brand and company in the eyes of the public, being crucial for attracting talents, as well as for the satisfaction, engagement and retention of employees in an organization.

Keywords: Employer Branding. Employer Brand Management. Competitive differential. Case study. Unconventional marketing applications. 


\section{INTRODUÇÃO}

Em um cenário de mercado crescentemente complexo e competitivo, a busca por profissionais competentes se torna progressivamente mais acirrada pelas empresas a fim de se obter excelência em seus serviços. A tendência é que, cada vez mais, o fator humano e suas perspectivas sejam reconhecidos como um dos recursos mais preciosos para o sucesso ou fracasso das organizações, se não imprescindíveis.

Levando em consideração o contexto de transformações organizacionais apresentado, e aliando isso às mudanças de desejos e de anseios das pessoas, é certo que as organizações necessitam evoluir. Diante desta situação, as estratégias organizacionais vêm convergindo-se fortemente com as práticas de seleção e retenção de talentos, buscando tomadas de decisões cada vez mais competitivas frente ao mercado. O processo de experiência do cliente, seja ele comprador direto ou candidato, inicia-se no valor que é atribuído a determinada organização e como isto é compreendido pelo público externo.

De acordo com uma pesquisa realizada com jovens profissionais, conduzida pela Revista Forbes, em 2017, os valores desta geração millenials estão trazendo um impacto drástico na forma de atuação das empresas (ALTON, 2017). A matéria ressalta que esses jovens não escolhem meramente negócios para trabalhar, mas sim analisam mais profundamente as empresas das quais compram e trabalham, com seus valores e cultura. Nesse sentido, $70 \%$ dos pesquisados se declararam dispostos a gastar mais com marcas que apoiam as causas com as quais se preocupam, bem como consideram para trabalhar marcas com ações de Diversidade e Inclusão e Work-Life Balance. Esses resultados apontam que as principais tendências dos profissionais (geração de novos profissionais) estão associadas a encontrar uma organização que os deixem mais perto de atingir seus objetivos pessoais, que tenham consonância com seus valores e que contribuam para a vida do indivíduo através dos objetivos organizacionais existentes dentro da empresa.

Como resposta a esse novo cenário e no intuito de sanar essas demandas, houve uma aproximação entre as áreas de Gestão de Pessoas e Marketing, originando-se o conceito (e decorrente prática) da Marca Empregadora, ou Employer Branding. Apesar disso, deve-se ressaltar que em muitas organizações, a área de Recrutamento e Seleção é a responsável por desenvolver e interligar estratégias de Employer Branding às práticas de atração de talentos, com foco no fortalecimento de marca no mercado.

A marca do empregador é uma abordagem relativamente nova para recrutar e reter o melhor talento humano possível dentro de um ambiente de recrutamento cada vez mais competitivo (BACKHAUS; TIKOO, 2004). Desta forma, o termo é frequentemente usado para descrever como as organizações comercializam suas ofertas para funcionários em potencial e se comunicam com eles, promovendo dentro e fora da empresa uma visão clara do que torna uma empresa diferente e desejável como empregador.

Além disso, a marca do empregador identifica uma organização no mercado e a torna única, fornecendo a todos os seus colaboradores uma noção do que ela é, bem como aos interessados em fazer parte dela, uma imagem clara do que esperar (GILLIVER, 2009; GOSWAMl; AGARWAL, 2015). Ela infunde o processo de recrutamento da empresa e a interação entre as pessoas na organização. Assim, a marca empregadora pode ser vista como uma estratégia que visa a construção e a manutenção de uma imagem positiva e atrativa de uma empresa, por meio da própria visão e/ou vivência de seus próprios colaboradores. Neste sentido, a construção de uma marca empregadora deve se iniciar com um trabalho interno de satisfação dos funcionários, para que a partir disso, seus valores e percepções possam ser difundidos para o mercado.

É possível entender que para atrair talentos e ser competitivo frente ao cenário de mercado atual, as empresas precisam trabalhar sua marca empregadora, fortalecendo sua relação com clientes, consumidores e colaboradores, para assim, tornarem-se atrativos para o público. Além disso, a finalidade não se limita em apenas atrair candidatos com capacidades e habilidades mais aderentes às oportunidades, mas também aqueles que tenham valores e características pessoais alinhados à cultura da empresa, gerando relacionamentos duradouros.

Diante deste contexto, o presente estudo tem como objetivo analisar a compreensão e utilização do Employer Branding em uma organização multinacional do ramo farmacêutico. Desse objetivo geral, depreende-se os seguintes objetivos específicos: compreender o conceito e os benefícios das estratégias de Employer Branding nas práticas de Recrutamento e Seleção; entender como o conceito de Marca Empregadora pode ser utilizado estrategicamente e seus efeitos nas organizações através da área de Gestão de Pessoas; verificar um estudo de caso, analisando as ações realizadas na empresa investigada, bem como entendendo a percepção de seus colaboradores acerca disso. 


\section{EMPLOYER BRANDING / MARCA EMPREGADORA}

Diante do cenário de demanda por profissionais qualificados em todo o mundo, a concorrência no mercado de trabalho aumenta e as empresas estão colocando mais ênfase na criação de estratégias para diferenciarem a si mesmas. Nesse sentido, relativamente recente, surge o conceito e decorrente prática de Employer Branding, ou marca empregadora.

O conceito inspirador surgiu na Europa, na década de 90, em um artigo publicado pelos autores Ambler e Barrow (1996) no Journal Of Brand Management. O estudo buscou testar a aplicação de técnicas de gerenciamento de marca com as de Gestão de Pessoas, por meio de uma pesquisa qualitativa com os principais executivos de 27 empresas do Reino Unido. A partir da reflexão de suas próprias práticas de gestão de pessoas, os executivos assentiram para a relevância de uma marca com valor empregatício no mercado e estão mais conscientes do nome de sua empresa ou marca, tanto explicitamente no ambiente externo quanto implicitamente nas configurações internas.

A partir disso, o conceito começou a ser disseminado, e a prática se tornou amplamente adotada pelas organizações em todo o mundo. Ambler e Barrow (1996) trazem uma argumentação de analogia entre a marca e a marca empregadora, afirmando que também o Employer Branding é detentor de uma personalidade, podendo ser igualmente posicionado interna e externamente. Em complemento, a questão do diferencial é mencionada, no sentido de que, para desenvolver uma marca empregadora forte, torna-se necessário demonstrar o que é específico sobre a organização e sua cultura, visando o longo prazo. Além disso, os autores mencionam que a Marca Empregadora não pode ser vista apenas como uma ferramenta de Recrutamento e Seleção, mas sim uma estratégia alinhada com o negócio da organização, que vise a atração e retenção de seus colaboradores de forma integrada e contínua.

Em sentido similar, Kusce e Okan (2010) defendem que a Marca Empregadora se torna cada vez mais essencial para as organizações na construção e manutenção de uma forte marca interna e externa. Tal processo seria imprescindível para a garantia de fatores como desempenho, comprometimento e lealdade dos funcionários no trabalho. Além disso, a Marca Empregadora é considerada benéfica não só para os já presentes funcionários, mas para os possíveis novos colaboradores. Assim, os autores reforçam a importância de a organização ser reconhecida como um ótimo lugar para se trabalhar na mente dos candidatos externos, a fim de que não necessariamente atraia o maior número de profissionais às suas vagas, mas sim os mais adequados para tais posições.

Corroborando com isso, Mascarenhas (2017) define a Marca Empregadora como um conceito referente à gestão de marca da empresa para sua força de trabalho, voltada tanto aos atuais colaboradores, aos futuros candidatos, bem como, àqueles que já encerraram sua jornada na organização. O valor da Marca Empregadora está associado ao seu grau de reconhecimento e a imagem que transmite às pessoas, além da diferenciação e lealdade (HOLLIDAY, 1997; REIS; BRAGA, 2016). Em consonância, Ahmad e Daud (2015) ressaltam a Marca Empregadora como uma abordagem atual que pode apoiar empresas efetivamente em seus esforços para contratar e reter seus colaboradores, contribuindo para o fortalecimento da marca corporativa e colocando a organização em um espaço de alta visibilidade e atratividade.

A estruturação da Marca Empregadora em uma organização consiste em algumas dimensões, segundo apontado por Hadi e Ahmed (2018): valor de interesse, de desenvolvimento, de aplicabilidade, social e econômico. Esses valores se distinguem em relação ao grau de apelação de fornecimentos diversos. O valor de interesse, por exemplo, decorre da oferta de situações de trabalho com oportunidades de inovação e criatividade. De maneira similar, o valor de desenvolvimento denota a possibilidade de experiência e aprimoramento profissional. Também vinculado, o valor de aplicabilidade configura a oportunidade de treinar e de fato exercitar o aprendizado trazido ou recebido. Já o valor social diz respeito ao ambiente de trabalho com espírito de equipe bom e acolhedor e relações respeitáveis e decentes entre colegas de trabalho. Por fim, o valor econômico se relaciona às políticas de remuneração e possíveis bonificações.

Ainda, mais recentemente, outras duas dimensões foram adicionadas, segundo a proposição de Dabirian, Kietzmann e Diba (2017): valor gerencial e de equilíbrio pessoal-profissional. Assim, o valor gerencial adicionaria a questão das eventuais influências (positivas ou negativas) dos profissionais em cargos de chefia, como supervisores, gestores, chefes, entre outros. Já o valor de equilíbrio pessoal-profissional, como o próprio nome sugere, considera que os funcionários também são pessoas que possuem uma identidade fora da organização; dessa forma, o equilíbrio entre trabalho e vida social contribuiria para que eles trabalhassem de maneira mais eficiente e eficaz.

Além disso, após o entendimento das estratégias de elaboração da Marca Empregadora, especialmente concernente as suas dimensões, a sua implementação prática consistiria em três estágios, de acordo com Hadi e Ahmed (2018). A primeira etapa configura o desenvolvimento de uma proposta de valor atraente que inclua os benefícios que devem ser oferecidos aos colaboradores. Essa proposta de valor, 
também denominada de Employer Value Proposition (EVP) deve se basear em informações da cultura, estilo de gestão, impressões sobre o produto ofertado e imagem dos colaboradores atuais. $O$ segundo passo concentra a comunicação da proposição de valor desenvolvida e projetada no primeiro estágio, direcionando-a aos meios de comunicação adequados. E, por fim, o terceiro ponto está relacionado à incorporação e implementação da proposta de valor criada. Por esse motivo, essa definição e proposição de valor empregatício (Employer Value Proposition - EVP) é visualizada como o primeiro passo para o desenvolvimento da Marca Empregadora, conforme também defendido por Mascarenhas (2017).

\subsection{Employer Value Proposition (EVP)}

Nas últimas décadas, grande parte do valor atribuível às empresas mudou de tangível para intangível, evidenciando os funcionários como os principais condutores desses ativos, devido à possibilidade de informações e conhecimento, bem como a capacidade de tomada de decisão frente diferentes opções. Como resultado, a capacidade de uma empresa atrair, reter e engajar talentos passou de bom para necessário (BLACK; MANOHAR; STEHLI, 2013). Segundos os autores, isso demanda uma quebra de paradigma da visão míope e simplista acerca do corpo de funcionários, com as inerentes questões de necessidades, motivação e satisfação, no sentido de se avançar para a compreensão e posterior construção de superiores proposições de valor empregatício.

Sendo assim, essa proposição de valor empregatício, ou Employer Value Proposition (EVP), englobaria todas as principais razões pelas quais os indivíduos escolheriam certa empresa para trabalhar ou pelas quais os presentes funcionários manteriam seu interesse em nela permanecer (VERGARA, 2016). Desta forma, defende-se o EVP como uma ideia que vem se desenvolvendo nos últimos anos e que indica o engajamento, como vinculação intelectual e emocional, que mantém o colaborador na organização onde trabalha e engajado com o trabalho que executa (HEGER, 2007).

Assim como exposto anteriormente, Vergara (2016) também assente que a elaboração formal da EVP se configura como o primeiro passo para se estabelecer a Marca Empregadora de forma que represente, de maneira explícita e autêntica, a identidade de uma organização, bem como suas aspirações e necessidades. Ainda que consista em um processo variável, adaptável e peculiar a cada organização, de uma maneira geral, têm-se alguns atributos básicos, tidos como valiosos (VERGARA, 2016). Possíveis exemplos são: remuneração como toda forma de compensação do trabalho e dedicação; oportunidades de desenvolvimento pessoal e profissional; a estrutura organizacional, com todas suas características tangíveis e intangíveis; o trato com as pessoas, a reputação da alta gerência, o reconhecimento e as relações sociais; o apoio à diversidade, o estímulo à criatividade e inovação, bem como a postura de responsabilidade social; e a imagem da organização perante ao mercado, em especial segundo a satisfação do consumidor.

Para construir uma Marca Empregadora forte e bem-sucedida, as empresas devem compreender como as partes interessadas analisam e interpretam as informações veiculadas, criando e adaptando uma proposta de valor condizente a isso. Nesse sentido, a empresa deve se comprometer a entregar a proposta de valor (EVP) e da Marca Empregadora que promete aos seus colaboradores e ao público em geral (WATSON; REISSNER, 2014). Isso também se refere à preocupação em proporcionar experiências consistentes com o posicionamento da marca em todo o ciclo das pessoas na organização, da atração ao desligamento, passando por temas como remuneração, desenvolvimento, ambiente físico e cultura (MASCARENHAS, 2017).

Caso contrário, eventuais dissonâncias podem se difundir rapidamente na própria organização e nas redes sociais, prejudicando a imagem da empresa envolvida e fragilizando, assim, a credibilidade da marca (REIS; BRAGA, 2016). Os autores afirmam ainda que funcionários frustrados com o seu empregador podem ser mais perigosos do que a própria concorrência. Por outro lado, quando bem empregado, o EVP representa a própria Marca Empregadora agregando diversos benefícios às organizações, conforme será discutido no subtópico seguinte.

\subsection{Benefícios do Employer Branding}

A Marca Empregadora pode trazer benefícios adicionais para a organização, na medida em que fornece uma justificativa para simplificar o gerenciamento, de forma a estabelecer e focar em prioridades (HOLLIDAY, 1997). Com isso, consegue-se aumentar a produtividade e melhorar os processos de recrutamento, garantindo um fluxo contínuo de candidatos adequados (HOLLIDAY, 1997).

Nesse sentido, podem ser apontados três principais benefícios da Marca Empregadora, relacionados ao recrutamento, desempenho e retenção, respectivamente (TAYLOR, 2010; WAHBA; ELMANADILY, 2015). Em primeiro lugar, o benefício do recrutamento consiste em, naturalmente, poder para atrair os talentos que são o foco da organização, sendo que uma marca empregadora forte ajuda a anunciar 
oportunidades e transmitir mensagens consistentes que alcançariam os melhores talentos. Do mesmo modo que as campanhas de marketing tradicional visam atingir apenas certos consumidores dentro do públicoalvo da organização, uma marca empregadora forte ajuda a empresa a alcançar os talentos mais adequados, reduzindo, assim, os recursos envolvidos no processo (dinheiro, tempo e esforços). Em segundo lugar, consegue-se aprimorar o desempenho dos funcionários, especialmente no sentido de maior comprometimento, melhoria de produtividade e até redução do absentismo. Por fim, em terceiro lugar, também se contribui para a retenção dos funcionários, com a redução da rotatividade, influenciando a experiência profissional por meio de um ambiente de trabalho saudável e motivadora.

Em complemento, defende-se a Marca Empregadora como essencial para a atuação organizacional, pois facilita a realização do plano de negócios, principalmente no caráter estratégico (VELOSO, 2018). Além disso, contribui para um reflexo mais acurado da identidade, valores e cultura da organização, aumentando a atratividade de candidatos que estejam alinhados às oportunidades em aberto, bem como impactando positivamente na produtividade dos funcionários. Como consequência, também auxiliaria na atuação exitosa da organização, amparando o contentamento do consumidor final.

\section{PROCEDIMENTOS METODOLÓGICOS}

O trabalho adotou um caráter qualitativo, de natureza descritiva, realizado por meio de estudo de caso. $O$ estudo de caso investiga um determinado fenômeno dentro do seu contexto de realidade, partindo do pressuposto de que as fronteiras entre o fenômeno e o contexto não são claramente definidas (STAKE, 2005). Para abarcar essa complexidade, é indicado a utilização de várias fontes de evidência, processo denominado de triangulação de dados. A triangulação reduz o risco de limitações, enviesamentos e parcialidades de um único método, contribuindo para uma descrição mais rica e detalhada do objeto-alvo de análise, conduzindo, assim, a conclusões mais credíveis (MAXWELL, 1996).

Neste estudo, a triangulação foi conseguida por meio da análise de dados secundários para a apresentação e caracterização da empresa escolhida, amparada na observação participante da pesquisadora como membro integrante dela, e levantamento de dados primários com a aplicação de entrevistas semiestruturadas, em profundidade.

A entrevista semiestruturada mantém um foco em um assunto de interesse, sobre o qual é elaborado um roteiro com perguntas principais, mas permite que haja complementação por outras questões inerentes às circunstâncias momentâneas à entrevista (MANZINI, 1990/1991). Assim, pode-se fazer emergir informações de forma mais livre e as respostas não estão condicionadas a uma padronização de alternativas.

Foram selecionados como sujeitos da pesquisa quatro gestores de distintas áreas e funções na organização, sendo elas: jurídica, serviços médicos, marketing digital e comercial. Esta estratégia foi pensada visando o mínimo de vieses possíveis na coleta de dados, já que cada colaborador terá visões distintas entre si, do que se fossem selecionados colaboradores de um mesmo departamento. Sendo assim, as entrevistas semiestruturadas possibilitaram um aprofundamento sobre a forma de como o Employer Branding é visto em ações do dia a dia nas organizações, entrelaçando -se com a experiência do colaborador, e, consequentemente, com a marca empregadora da organização. Nesse sentido, levou-se em consideração as particularidades dos entrevistados em uma análise ampla e não mensurável.

\subsection{Roteiro de entrevistas}

No âmbito de formulação das perguntas de entrevista, foi escolhido o método de sistematização por categorias do que se busca compreender (VERGARA, 2013). Esta categorização foi criada para agrupar as perguntas do roteiro de forma que pudessem ser analisadas em conjunto, bem como, para facilitar a alocação das informações adicionais compartilhadas pelos participantes, visto a flexibilidade do modelo semiestruturado.

A seguir, são expostas as referidas categorizações, juntamente ao objetivo associado a cada uma delas:

1- Pré-processo Seletivo: visão do colaborador sobre a organização antes de seu ingresso;

2- Durante o Processo Seletivo: percepção dos colaboradores enquanto participavam do processo seletivo, no sentido de como foi a experiência, em questão de tempo, qualidade do processo, interação com os recrutadores, bem como o processo admissional para ingresso na organização. organização;

3- Ingresso na Organização: satisfação do colaborador com o seu processo de ingresso na 
4- Permanência e Experiências na Organização: processo de permanência do colaborador na organização, analisando o quão confortável esse sente em expressar sua visão, opinião, propostas e feedbacks, bem como se indicaria a empresa para um colega trabalhar.

5- Entendimento sobre o que é o Employer Branding: conhecimento dos colaboradores em aspectos mais técnicos, como o que é o Employer Branding, qual sua importância e se a organização em estudo utiliza destas estratégias para com seus colaboradores. Decorrente do exposto, foram desenvolvidas questões, conforme Quadro 1.

\section{Quadro 1 - Estruturação do Roteiro de Entrevistas}

1 - Pré-processo seletivo

1.0) Quando você ficou sabendo da existência da empresa?

1.1) Você se lembra qual foi a sua primeira impressão no geral?

1.2) Por onde você tomou conhecimento? Páginas em redes sociais? Se sim, quais delas?

2.0) Após esta primeira impressão, ainda antes em pensar em ser colaborador, qual era sua percepção geral sobre a empresa?

2.1) Quando você pensava na empresa, o que te vinha em mente? Quais as primeiras associações?

3.0) Já pensando no seu processo seletivo, como você ficou sabendo dele e da vaga a qual você se aplicou?

3.1) Lembra da sua reação? O que você pensou quando leu o descritivo de vaga e outros pontos sobre a oportunidade?

3.2) Como você ponderou a decisão de participar deste processo? O que te motivou? Lembra dos prós e contras que foram analisados por você?

\section{2 - Durante o Processo Seletivo}

4.0) Como foi o seu processo seletivo na? Conte-me um pouco de como foi a sua experiência de contato com os recrutadores, etapas de entrevistas e processo de admissão.

5.0) Durante o processo seletivo, você se lembra de como se sentiu em relação à empresa?

5.1) Lembra das sensações que lhe percorriam? Por exemplo, "quero muito trabalhar aqui" ou era mais indiferente quanto a isso?

5.2) Houve alguma ação específica durante o processo que você ressalta como positiva?

5.3) Suas expectativas iniciais sobre a empresa e o processo em si, estavam sendo reafirmadas ou contraídas?

6.0) Após este contato, sua perspectiva sobre a empresa mudou? Como?

3 - Ingresso na Organização

7.0) Como foi o seu processo de on-boarding quando você foi admitido na empresa? Conte me sobre a sua experiência.

8.0) Você se sentiu integrado/engajado com a cultura, valores e princípios da empresa?

8.1) O que causou uma boa impressão?

8.2) Por outro lado, o que poderia ter sido melhor?

4 - Permanência e Experiências na Organização

9.0) Pensando na sua situação atual de trabalho, como você a definiria? Boa, ruim?

9.1) Você se sente satisfeito, realizado? Em que sentido?

10.0) Como você se sente com as experiências internas diárias que são promovidas aos funcionários? Como exemplo, treinamentos, workshops, espaço de troca de ideia e networking.

11.0) O que você identifica como pontos positivos e oportunidades de desenvolvimento?

12.0) Você se sente confortável em seu ambiente de trabalho?

12.1) Sente que pode expressar sua visão, opinião, propostas e feedbacks na empresa?

12.2) Sente-se engajado a responder pesquisas de satisfação no trabalho, como as do Great Place to Work?

13.0) O que você mais valoriza na empresa?

14.0) Qual o diferencial que você acredita que a empresa possui?

14.1) Exemplos como qualidade de vida, oportunidade de crescimento de carreira etc.

15.0) Como você acha que é a sua imagem como colaborador da empresa? Ou seja, como os outros te veem acerca disso?

16.0) E como você mesmo se vê?

5 - Entendimento sobre o que é o Employer Branding

16.0) Você sabe dizer o que é o Employer Branding ou Gestão de Marca Empregador?

16.1) Sabe como ele funciona? Quais as principais ações vinculadas?

17.0) Você diria que a empresa pratica o EB? Pode compartilhar suas impressões sobre isso?

17.1) O que fica mais evidente para você? Em termos de ações.

17.2) O que fica faltando?

18.0) Algo mais que você gostaria de compartilhar sobre essa temática? 


\subsection{Coleta e análise de dados}

As quatro entrevistas com gestores de diferentes áreas da organização foram realizadas no mês de maio de 2020, via Microsoft Teams, uma ferramenta de comunicação digital. As reuniões foram previamente agendadas, tiveram duração média de 35 minutos (variando entre mínimo de 30 minutos e máximo de 50 minutos) e foram gravadas.

As entrevistas foram conduzidas de acordo com o roteiro apresentado acima, servindo como uma base do direcionamento das perguntas, mas não como limitante. Tal fato possibilitou o surgimento de informações adicionais por parte dos entrevistados, que se mostraram bastante confortáveis durante as interações.

Foram selecionados gestores de quatro áreas distintas da empresa, que serão brevemente apresentadas a seguir: jurídica, serviços médicos, digital marketing e comercial. A área Jurídica é responsável por alinhar os objetivos e operações da organização com os dispositivos legais preestabelecidos, de forma que ela siga a lei em suas ações. Atualmente, é composta por cinco funcionários, dentre eles estagiários, analistas e gestores. A Área de Serviços Médicos é bastante estratégica, visto que fica encarregada da interação com os clientes no que se diz respeito à utilização dos medicamentos, ou seja, age como um portavoz para dúvidas e comentários quantos aos produtos da organização. Atualmente emprega 37 pessoas, variando entre gerentes, coordenadores, analistas, estagiários e aprendizes. Já a área de Digital Marketing é uma das mais recentes, ganhando sua diretoria no ano de 2019 e, a partir disso, crescendo exponencialmente em relação a contratações de novos colaboradores. Ela trabalha com a promoção dos produtos, marcas e lançamentos no ambiente on-line. Por fim, a área comercial é responsável por desenvolver o relacionamento com os pacientes, médicos, hospitais e farmácias a fim de expor os produtos e conectar as soluções da empresa às necessidades do consumidor. Além disso, o departamento comercial conta com equipes em todos os estados do Brasil, divididos em times com Gerentes Distritais, Supervisores de Vendas, Promotores, KAMS (Key Account Manager) e estagiários, sendo a área com a maior demanda de novas contratações.

Após a coleta dos dados, com a gravação das entrevistas realizadas, elaborou-se relatórios detalhados, possibilitando o emprego da técnica de análise de conteúdo. Com ela, buscou-se compreender a essência e o significado dos dados coletados, bem como traduzir o entendimento dos conteúdos através de certa classificação, apresentada de forma sistematizada. Isso possibilitou o destaque de determinados trechos, bem como posteriores comparações entre os relatos dos diferentes entrevistados, seja no sentido de concordância ou discordância.

\section{CARACTERIZAÇÃO DA EMPRESA ANALISADA}

O mercado farmacêutico brasileiro vem crescendo ano após ano, impactando a vida de milhares de pessoas no país. Segundo o Estudo de Mercado Institucional da IQVIA, empresa global associada a soluções de auditoria, tecnologia e consultoria para o mercado de saúde, o mercado farmacêutico brasileiro alcançou vendas de $\mathrm{R} \$ 215,6$ bilhões em 2019. Além disso, o setor está em mudança devido à nova onda de lançamentos das indústrias farmacêuticas, que buscam soluções, principalmente, para oncologia, depressão, Alzheimer e doenças raras. Destes problemas mencionados, em sua maioria, possuem tratamentos de alto custo e que não podem ser tratados em farmácia tradicional, mas sim em ambiente hospitalar. Neste contexto, apesar das eventuais crises que assolam o Brasil, o mercado farmacêutico consegue seguir crescendo e expandindo seus negócios. Isso se deve, principalmente, ao fato de que os medicamentos são essenciais no tratamento e cura de muitas doenças e por isso, independente da conjuntura em que o país se encontra, as demandas nas áreas de cuidado com a saúde sempre irão existir em canais públicos ou privados.

A empresa foi criada em 1996 com a fusão de duas outras empresas do ramo químico industrial: a Ciba-Geigy, que também resultou de uma fusão anterior, entre as empresas Geigy e Ciba, ambas fundadas na Suiça, em meados do século XVIII, e a Sandoz, cuja atuação se iniciou em 1886, também na Suiça. Por isso, na verdade a empresa soma um passado de mais de 250 anos com uma história rica no desenvolvimento de produtos inovadores, compartilhando o desejo de criar e comercializar produtos que trouxessem algum tipo de contribuição para o progresso humano. No Brasil, já são mais de 80 anos de história, e hoje, a empresa conta com aproximadamente 2.700 funcionários e beneficia mais de 30 mil pacientes em mais de 300 centros de pesquisa espalhados pelo país. Além da sede administrativa em São Paulo, e dos escritórios localizados em diversas cidades, o grupo também conta com duas unidades fabris: uma no Butantã, focada na produção de produtos farmacêuticos para tratamentos oftalmológicos, e outra em Cambé, no Paraná, focada na produção de medicamentos genéricos. 
A estratégia da empresa é trabalhar com a inovação, baseada na ciência, para proporcionar os melhores resultados aos pacientes, desde a melhora do custo-efetividade de um medicamento, da alta qualidade nos cuidados oferecidos, até o prolongamento da vida. Além disso, mantém um investimento significativo em Pesquisa \& Desenvolvimento (P\&D) destinado a áreas de necessidades médicas não atendidas, como as de imuno-oncologia, envelhecimento e medicina regenerativa e de doenças infecciosas.

Além disso, as movimentações mais recentes foram realizadas pensando em deixar no portfólio apenas as divisões que recebiam maior destaque, possibilitando assim um maior foco no direcionamento dos investimentos. Com isso, a formatação atual da empresa conta com quatro principais divisões, sendo elas:

1. "NBS - N Business Services": centro de serviços compartilhados que engloba diversas áreas de serviços dentro da empresa que atendem os colaboradores internos, independentemente da divisão em que estão. Algumas destas áreas são: compras, tecnologia da informação, remuneração \& benefícios, e recrutamento \& seleção.

2. "S": divisão específica para genéricos e biossimilares. Os genéricos são produtos que eram produzidos por uma única empresa, mas que depois de um tempo perdem a patente, e passam a ser produzidos por todas as outras. Os biossimilares são como se fossem genéricos dos medicamentos biológicos, que possuem composição bastante complexa por se tratar de matéria-prima biológica, viva.

3. "O": o portfólio desta divisão engloba produtos para tumores líquidos (hematologia), tumores sólidos e doenças raras. Atualmente, é a divisão com maior faturamento do grupo, e com a maior expectativa de crescimento também.

4. "P": divisão que foca em medicina inovadora, com produtos nas áreas terapêuticas de cardiovascular e metabólico, respiratória, imunologia e dermatologia, ophta (medicamentos oftalmológicos), neurológicos, entre outros.

\subsection{Employer Branding na empresa}

Para garantir sua razão de existência, a empresa vem investindo fortemente em contratações estratégicas, que chegam em média a 250 por ano no Brasil (como em 2019, tendo 267 processos seletivos concluídos), incluindo posições de aprendizes, estagiários e efetivos. Destas posições mencionadas, cabe destacar que $61 \%$ foram ocupadas por mulheres e $39 \%$ por homens, o que demonstra o comprometimento com a oportunidade e igualdade de gênero dentro da organização. Além disso, do total de processos realizados, $43 \%$ são posições seniores, envolvendo cargos de gestão, o que indica a necessidade do negócio em posições mais estratégicas, e $57 \%$ delas, em cargos de baixa senioridade.

Atualmente, na empresa não existe uma área estruturada que fica responsável unicamente pelas estratégias de Employer Branding da organização, passando a ser um trabalho conjunto entre as áreas de Comunicação, Recrutamento e Seleção e Gestão de Pessoas. A área de comunicação é responsável pelo gerenciamento das redes sociais e dos materiais publicitários que serão divulgados, estruturando a primeira imagem que o público externo e possíveis talentos para oportunidades terão contato. A área de Recrutamento e Seleção representa o contato real da empresa para com o público externo e após isto, a área de Gestão de Pessoas fica responsável pelo acolhimento dos novos e atuais colaboradores da organização.

Nesse sentido, por envolver áreas diferentes, pode-se argumentar que o processo do Employer Branding acaba não sendo visualizado como um todo na empresa em questão, tampouco de maneira conjunta, o que pode prejudicar a análise das informações e de possíveis pontos de melhoria para a experiência do candidato e futuro colaborador. Este ponto foi mencionado por Veloso (2018), ao argumentar que a Marca Empregadora cria a necessidade de misturar as competências das áreas de Recursos Humanos e Marketing, demandando também o envolvimento de outros departamentos, principalmente no sentido de direcionamento estratégico organizacional. Em consonância, Banta e Watras (2019) apontam que o maior problema das ações de Marca Empregadora é o de que elas estão desconectadas das estratégias organizacionais e dos principais motores do negócio, pois normalmente são gerenciadas apenas pelo time de Recursos Humanos, tornando-as mais limitadas à apenas divulgação de benefícios. Com base nisso, defendese que uma área dedicada apenas ao desenvolvimento das estratégias de Employer Branding conseguiria concentrar tais esforços, interagindo e integrando-se aos demais departamentos, bem como realizar os trabalhos de acompanhamento e eventuais avaliações, com possíveis ações de melhoria.

Em relação à divulgação das vagas em aberto, as principais fontes de conhecimento e acesso a elas são o site de vagas oficial da empresa, que traz mais engajamento e confiança à marca, seguido da sua página do Linkedin, o que gera maior alcance e visibilidade. A referida página possui cerca de 2,5 milhões de seguidores ao redor do mundo, expondo, além das vagas, conteúdos sobre a cultura da empresa, ações, medicamentos, histórias de colaboradores, premiações e novidades em geral. Essas estratégias de mídia colaboram na construção dos pilares de visibilidade e engajamento do público com a empresa, conforme 
defendido por Ahmad e Daud (2015) e Reis e Braga (2016). Segundo uma pesquisa realizada pela empresa junto aos candidatos, em 2019, 40\% dos respondentes informaram que souberam da vaga por indicação de algum colaborador, seguidos de $30 \%$ que a visualizaram no site oficial da empresa e $21 \%$ através do Linkedin; do restante, $8 \%$ mencionaram o pipeline ou banco de talentos e $1 \%$ a plataforma do Vagas.com. Ou seja, ainda que a empresa trabalhe com as fontes formais de divulgação, a recomendação do público interno representa o ponto mais representativo de disseminação de vagas. Esse resultado também se mostra congruente com o levantado pela teoria, segundo Mascarenhas (2017).

A seguir, serão expostos os principais fatores que embasam a estratégia de Employer Branding adotada na empresa, tais como: cultura e ambiente organizacional, inovação, treinamento e desenvolvimento, remuneração e benefícios, influência da gestão, qualidade de vida diversidade e inclusão, entre outros. Esses pontos estão em consonância com o apresentado pelos autores Dabirian, Kietzmann e Diba (2017) que afirmam que estes fatores são críticos e essenciais para os profissionais avaliarem e considerarem uma empresa para se trabalhar.

\subsection{Cultura organizacional e valores}

Valores e filosofias moldam a cultura de uma organização e ajudam a executar a estratégia da mesma, de acordo com seu propósito, missão e visão e estes atributos e propostas de valor, são importantes para que o Employer Branding traga bons resultados, segundo Reis e Braga (2016). Nesse contexto, a cultura organizacional também representa as percepções da liderança e dos colaboradores, assim como reflete a forma de pensar, ou mindset, que predomina na organização. Isso significa que a cultura corporativa é a representação das normas não escritas e informais que orientam o comportamento das pessoas em uma empresa. Nesse sentido, a cultura da empresa se pauta pelos seguintes principais pilares: "não chefia" (unbossed), "inspiração" (inspired), "curiosidade" (curiosity) e "integridade" (integrity). Cada um deles está inserido no dia a dia dos colaboradores e se refletem diretamente em suas ações, além de serem pilares incentivados e divulgados pela liderança corporativa interna e externamente.

A "não chefia" diz respeito à cultura da não hierarquização das relações e ações dentro da organização, tendo um efeito direto na disposição da estrutura física das salas de trabalho, que hoje não distinguem nem separam a alta liderança. Isso denota um ambiente mais aberto e flexível, no qual diferentes cargos e funcionários trabalham juntos. Além disso, contribui-se para que os funcionários se sintam mais à vontade para expressar suas ideias, trocar compartilhamentos, dar e receber feedbacks, bem como acaba por incentivar os processos inovativos. Relacionado a isso, o "inspirado" diz respeito à inovação e abertura ao novo, oferecendo um ambiente que incentive o experimento de novas soluções para os problemas vividos. No "curiosidade", busca-se, novamente, reforçar a busca pelo novo, no sentido de formas inovadoras de soluções, de maneiras de trabalhar e de relacionamento com o outro. Isso também é bastante incentivado por meio da disponibilização de plataformas de conhecimento, que estimulam os funcionários a buscarem aprendizado e capacitação profissional. Por último, a "integridade" se refere à defesa e aplicação de altos padrões éticos diariamente, nas decisões, ações e comportamentos tidos tanto no ambiente de fábricas, quanto no escritório corporativo.

\subsection{Diversidade e Inclusão}

O modo como as empresas encaram o tema de diversidade e inclusão interfere diretamente na visibilidade e fortalecimento de uma marca empregadora, principalmente quando o colaborador e o público externo avaliam o discurso organizacional, contrastando-o à prática real. Diante disso, segundo Hadi e Ahmed (2018), o valor da diversidade é um dos valores agregados às dimensões da marca do empregador, fortalecendo o Employer Branding praticado e diferenciando a empresa perante o mercado.

$\mathrm{Na}$ empresa, tais questões se mostram presentes no dia a dia dos funcionários, com o cultivo de um ambiente abrangente, com foco no alto desempenho, que valoriza e aproveita as diferenças, criando um local de trabalho que encoraja e considera as ideias de todos. Além disso, a empresa parece entender que, à medida que os seus clientes se tornam cada vez mais diversos, um grupo de funcionários com talentos diversos e bem qualificados se torna crítico para melhor entender e atender as necessidades desse público de forma inovadora. Por isso, existem diversas ações que promovem o engajamento de todos os colaboradores da organização, inclusive com as supracitadas temáticas, por meio de comitês, rodas de conversa, palestras e workshops. 


\subsection{Treinamento e Desenvolvimento}

A empresa possui uma área específica de Treinamento e Desenvolvimento, focada no estudo e desenvolvimento de estratégias que possibilitem novos aprendizados aos funcionários, bem como apoio à construção de seus planos de carreira. Trata-se de uma área chave, visto que lida com alcance de objetivos, desenvolve competências, discute questões de cultura, visão, valores e clima organizacional, além de manter o corpo de funcionários alinhado e engajado com o negócio da empresa.

A empresa trabalha com diversas plataformas de aprendizado, oferecendo diversidade de cursos, palestras, podcasts, artigos e descontos em escolas de idiomas. Como exemplo, todos os funcionários da organização, de estagiário a presidente, possuem acesso à plataforma de aprendizado do Linkedin, chamada Linkedin $E$ - Learning, bem como do Coursera, com centenas de cursos e conteúdos disponíveis e totalmente gratuitos. Nesse sentido, a comunicação da empresa também possui papel fundamental nessa estratégia de desenvolvimento, trabalhando com divulgação dos cursos, aulas práticas de como utilizar as plataformas e reforçando a importância de engajar os colaboradores neste benefício, que é um diferencial de mercado.

Além disso, caracteriza-se como instrumento de boas práticas, assegurando a competitividade dos negócios em mercados cada vez mais acirrados, por tornar seus colaboradores mais capacitados frente aos novos desafios, bem como ser um atrativo frente à concorrência. Assim, são diversos os benefícios desse fator, tais como o aumento da produtividade e do engajamento dos colaboradores, a redução do turnover, e o empoderamento desses profissionais para enfrentarem desafios futuros. Em linha com essas ideias, como mencionam Ahmad e Daud (2015), por conta da alta competitividade do mercado, a maioria dos funcionários hoje em dia busca principalmente um empregador que forneça programas de desenvolvimento de carreira dentro da organização, pois essas são as oportunidades que Ihes assegurariam um futuro brilhante.

\subsection{Remuneração e Benefícios}

A empresa investe em faixas salariais competitivas e compatíveis com as do mercado, associadas a um pacote de vantagens e benefícios que colaborem com a retenção de talentos perante à competitividade do mercado. Além disso, configuram-se como atributos de atração fundamentais com base na proposição de valor de uma organização, conforme exposto anteriormente por Reis e Braga (2016). Entre eles, observa-se que a empresa oferece bônus/PPR anual, previdência privada, seguro de vida, um mês de férias por ano, recesso de final de ano, políticas de home office e horário flexível, day-off aniversário, licença-maternidade e paternidade, auxílio creche para pais e mães, refeitório subsidiado, vale-alimentação, assistências médica e odontológica, convênio farmácia, concessão gratuita de medicamentos da empresa, empréstimo consignado, estacionamento gratuito, convênio com Gympass, Espaço de saúde Energized for Life e academia no local para colaboradores da área administrativa. Todos esses benefícios também compõe as estratégias de Employer Branding da empresa e interferem diretamente na satisfação e engajamento de seus colaboradores. Além disso, a empresa também avalia a percepção dos seus funcionários acerca dos presentes critérios de remuneração e benefícios. No ano de 2019, por exemplo, obteve uma nota de avaliação de 3,9, em uma escala de 0 a 5 , atribuída por 4 mil funcionários.

\subsection{On-boarding}

O processo de ingresso (on-boarding) é realizado por meio de um conjunto de procedimentos que têm como objetivo envolver, encantar, incluir e capacitar os profissionais recém-ingressados em uma organização dentro de sua cultura. Trata-se da primeira oportunidade de acolher o novo funcionário, incluindo-o na organização.

Apesar da empresa trabalhar com essa prática, não é possível identificar um plano bem definido, tampouco a delimitação de uma área responsável por isto. Tal fato pode acarretar em uma primeira impressão ruim sobre a comunicação no ambiente de trabalho, assim como prejudicar esse processo de transmissão de informações essenciais a esse novo funcionário, já que o on-boarding é o momento de inserção do novo colaborador à cultura organizacional, valores e missão de uma empresa, segundo Cable, Gino e Staats (2013).

No primeiro dia de trabalho, promove-se uma reunião de integração, que traz uma apresentação geral sobre a empresa, seus valores, missão e a estratégia adotada por algumas áreas administrativas, bem como a exposição dos benefícios ao qual este colaborador terá direito. Ainda que se trate de uma etapa necessária e bem desempenhada pela empresa, pode-se mencionar a ausência de treinamentos específicos que abordem temas estratégicos de suas áreas, aprofundando-se em tarefas e stakeholders com os quais irão trabalhar diretamente. Nesse sentido, argumenta-se que para uma efetiva aplicação de estratégia de Employer 
Branding, é essencial que exista uma comunicação interna eficaz com os funcionários, a fim de se promover e colher todos os benefícios citados anteriormente no decorrer dessa discussão. Por isso, uma alternativa para melhorar essa comunicação seria a criação e disponibilização de um material síntese, que ofereça informações relevantes sobre o negócio, permeando assuntos como a empresa, sua cultura organizacional e pilares, suas boas práticas, bem como guia de acolhimento e primeiros passos.

\subsection{Prêmio Great Place to Work - Melhores Empresas para se Trabalhar}

Com o objetivo de analisar a impressão dos funcionários, a empresa participa de uma certificação global chamada Great Place To Work, que realiza o diagnóstico da cultura e do clima organizacional. Ela conseguiu a referida certificação nos anos mais recentes, tais quais 2018 e 2019. O estudo é baseado na avaliação do nível de confiança dos funcionários em cinco dimensões: credibilidade, respeito, imparcialidade, orgulho e camaradagem. Assim, o questionário engloba questões como ambiente de trabalho, qualidade de vida, valorização profissional, carreira, entre outros.

Esse certificado é reconhecido mundialmente, em mais de 60 países, o que garante grande visibilidade no mercado. Além disso, há significativa divulgação em torno dessa premiação, consolidando um fator a ser enaltecido pelos funcionários, bem como buscado por novos talentos. Como resume a própria certificação, é considerada uma boa empresa para trabalhar aquela que acredita em seus funcionários, e que estes acreditam em suas lideranças, além de terem orgulho do que fazem e se sentirem confortáveis no ambiente de trabalho organizacional. Interessante lembrar que este processo de posicionamento da imagem de uma empresa como ótimo lugar para se trabalhar na mente dos candidatos é um dos pilares das estratégias de marca empregadora, como afirmam Kusce e Okan (2010).

\section{APRESENTAÇÃO E ANÁLISE DAS ENTREVISTAS}

Essa seção se encontra estruturada em seis tópicos principais, as cinco categorias de questionamentos (pré-processo seletivo, durante o processo seletivo, ingresso na organização, permanência e experiências na organização, entendimento sobre o que é o Employer Branding), bem como uma discussão geral dos resultados encontrados.

Os entrevistados foram codificados, a fim de se manter a fluidez da leitura, sendo: gestor da área jurídica como GJ, gestora da área de Serviços Médicos como GSM, gestora da área de Digital Marketing como GDM e gestor da área de Força de Vendas como GFV.

\subsection{Pré Processo Seletivo}

A primeira parte das entrevistas buscou entender qual a visão dos entrevistados sobre a empresa antes do processo seletivo, ou seja, quais suas primeiras impressões sobre a organização, como ficaram sabendo das vagas às quais se candidataram e como ponderaram a decisão de se tornarem colaboradores da organização.

O GJ ingressou na empresa há 15 anos e, naquela época, seu principal objetivo profissional era sair de escritório de advocacia e migrar para o segmento industrial. Por meio da indicação de um colega, ficou sabendo da existência da empresa e participou de um processo seletivo para uma posição de advogado temporário, mesmo tendo que abrir mão da vaga fixa em que estava. Ele recorda que já naquele período, as empresas farmacêuticas eram vistas com bons olhos, principalmente por conta da alta remuneração e benefícios aos seus colaboradores, sendo estes um dos pontos-chave para sua tomada de decisão. Além disso, comentou que o universo das empresas multinacionais era muito mais complexo e estruturado quando comparado às empresas nacionais, especialmente no que se diz respeito à processos administrativos internos, o que o proporcionaria grande aprendizado e desenvolvimento aos colaboradores.

A GSM foi admitida em 2015, como indicação para substituir uma colega de trabalho que estava saindo da empresa. Ela ingressou como colaboradora terceira com foco em melhoria de processos da área de Serviço de Informação ao Cliente (SIC). Além disso, assim como o gestor do jurídico, comentou que sempre ouviu comentários positivos sobre a empresa, principalmente no que se diz respeito à benefícios, qualidade de vida, compromisso com a sustentabilidade, oportunidade de desenvolvimento e crescimento profissional. Por conta disso, enxergava a organização com bons olhos e tinha interesse em trabalhar e desenvolver suas habilidades como parte do time. 
Já a GDM foi admitida em 2017 e comentou que conheceu a empresa há muito tempo, em sua época de faculdade, pois tinha colegas que trabalhavam na organização e comentavam sobre. Além disso, em uma de suas experiências na indústria farmacêutica, entrevistou alguns talentos para sua área, os quais já haviam trabalhado na organização e comentavam sobre cultura, valores, negócio e modelo de trabalho desta, o que chamou atenção da gestora entrevistada. Um ponto interessante que a entrevistada levou em consideração para sua tomada de decisão referente ao ingresso na empresa, foi a questão da maternidade, pois um de seus maiores sonhos era ter filhos e ela sabia que teria autonomia e bem-estar para gerenciar seu trabalho e vida pessoal nesta organização, muito por conta das experiências que foram compartilhadas. Apesar dos pontos positivos, se recorda também que muitos ex-colaboradores comentavam sobre a questão de hierarquização na organização, o que dificultava o crescimento dos profissionais e gerava um sentimento de desvalorização. Diferentemente dos outros entrevistados, ela mencionou que não se candidatou diretamente a nenhuma vaga na companhia em estudo, mas que um dos headhunters dela entrou em contato proativo com ela para entender sua situação profissional e interesse em novas oportunidades.

Por fim, o GFV ingressou na empresa em dois momentos distintos, o primeiro como estagiário, em 2007 e o segundo, como efetivo, em 2017. Além disso, comentou que conheceu a empresa quando ainda estava cursando a faculdade e lembra que se familiarizou com a maior parte dos medicamentos genéricos que ela produzia, mas que não os associava à organização em si. No momento em que buscava áreas e oportunidades para estagiar, um de seus principais interesses era a Força de Vendas e Inteligência de Mercado e foi através do CIEE (Centro de Integração Empresa Escola) que encontrou uma posição em aberto que convergia com seus interesses. Também destacou que a mensagem do "propósito de cuidar", valores da organização e o alto salário para a posição de estágio, o engajaram a participar do processo seletivo. Após este período, no segundo momento de entrada na empresa, o que o despertou interesse foi a admiração que possuía pela mesma por conta de suas experiências anteriores e a busca por desenvolvimento profissional.

\section{Quadro 2 - Síntese dos relatos - Pré-processo seletivo}

\begin{tabular}{|c|l|}
\hline GJ & $\begin{array}{l}\text { Principal objetivo profissional era sair de escritório de advocacia e migrar para a indústria. Conheceu empresa } \\
\text { por meio de indicação de colega de trabalho. Impressão positiva da indústria farmacêutica, principalmente por } \\
\text { conta da alta remuneração e bons benefícios aos seus colaboradores, os quais foram pontos-chave para sua } \\
\text { tomada de decisão. }\end{array}$ \\
\hline GSM & $\begin{array}{l}\text { Soube da oportunidade por indicação de colega de trabalho. Além disso, comentou que sempre ouviu falar } \\
\text { muito bem sobre a empresa, principalmente no que se diz respeito à benefícios, qualidade de vida, } \\
\text { compromisso com a sustentabilidade e oportunidade de desenvolvimento e crescimento profissional }\end{array}$ \\
\hline GDM & $\begin{array}{l}\text { Conheceu a empresa na época de faculdade através de comentários de colegas e após isso, entrou na } \\
\text { Indústria Farmacêutica. Principal ponto para a tomada de decisão foi a questão da maternidade, que era um } \\
\text { de seus objetivos e sabia que teria autonomia e bem estar para gerenciar trabalho e vida pessoal na } \\
\text { organização, muito por conta das experiências que as eram compartilhadas. }\end{array}$ \\
\hline GFV & $\begin{array}{l}\text { Conheceu a empresa quando ainda estava cursando a faculdade e lembra que se familiarizou com a maior } \\
\text { parte dos medicamentos genéricos que ela produzia, mas que não os associava à organização em si. Iniciou } \\
\text { sua trajetória na empresa como estagiário, através de processo com consultoria, e em um segundo momento, } \\
\text { retornou a empresa como gestor de vendas. }\end{array}$ \\
\hline
\end{tabular}

Fonte: Elaborado pelas autoras (2021).

De forma geral, todos os profissionais relataram ter boas impressões sobre a empresa, tendo em vista os comentários e indicações de colegas de faculdade e trabalho, principalmente ao que diz respeito à cultura, qualidade de vida, oportunidade de desenvolvimento, crescimento, bem como, benefícios e remuneração, e mesmo com diferentes períodos de ingresso, houve consonância de que esses fatores foram essenciais para a tomada de decisão de ser colaborador da companhia em estudo. Esses relatos reforçam a literatura levantada pela autora Mascarenhas (2017) que afirma que o recente espaço e a confiança em opiniões de empregados sobre as condições de trabalho em uma empresa fazem com que esses discursos sejam mais confiáveis e relevantes, já que estas pessoas tiveram um contato próximo com a organização, fortalecendo a marca empregadora da mesma e a priorizando frente à concorrência.

\subsection{Durante o Processo Seletivo}

Nessa segunda etapa, o objetivo foi compreender quais foram as experiências de cada entrevistado durante as etapas do processo seletivo para entrada na empresa. 
O GJ informou que estava bastante contente e animado com a oportunidade, mas que o processo de entrevistas não causou uma boa impressão, justificado pelo declarado despreparo e insensibilidade do entrevistador. Naquela época, o responsável por realizar os processos seletivos era o gerente de Recursos Humanos, que explicitou na entrevista que não havia nenhuma possibilidade de efetivação na empresa, visto que o entrevistado havia se candidatado a uma vaga temporária. Por conta disso, o GJ comentou que se sentiu extremamente incomodado com a situação, mas como migrar para a indústria era sua principal meta, vista como uma ótima oportunidade, acabou aceitando a proposta da vaga. Esta situação evidencia o quanto a própria área de recursos humanos foi se desenvolvendo, tornando-se mais próxima das pessoas e humanizada, atualmente.

A impressão da GM foi totalmente diferente, relatando ter sido uma experiência muito gratificante, respeitosa e transparente. Como se tratava de uma vaga terceirizada, ela passou por entrevistas com a empresa terceira, da área de Recrutamento e Seleção, e com os diretores médicos referente à vaga a qual se candidatou. Ela mencionou ainda que se sentiu engajada com a cultura da organização e motivada a continuar a competir pela vaga. Assim, a sua impressão positiva sobre a organização antes do processo se confirmou, e até melhorou após contato com os stakeholders envolvidos na seleção de sua vaga.

O processo seletivo da GDM foi peculiar, pois ela foi contatada diretamente por um dos headhunters da empresa, para conversar sobre sua trajetória profissional e entender seus anseios de carreira. No momento da abordagem, ela já estava em uma posição de liderança em outra empresa farmacêutica e ainda não havia uma posição em aberto que fosse aderente ao seu perfil e interesse na empresa, o que tornou este processo seletivo mais profundo, específico e demorado. Para tanto, foi criada uma vaga na organização, direcionada ao interesse da entrevistada e à estratégia estabelecida pela organização naquele momento, o que causou um sentimento de pertencimento e valorização por ela. Além disso, a gestora foi entrevistada pela própria headhunter junto dos dois presidentes da época, que foram muito receptivos e abertos, conquistando-a para que aderisse ao time da empresa em estudo.

Interessante que o GFV passou por dois processos seletivos na empresa, o primeiro para uma vaga de estágio e o segundo para uma posição efetiva. Na primeira experiência, ele comentou que todo o processo foi conduzido pelo CIEE, mas as entrevistas finais foram conduzidas pelos gestores da posição (representantes de vendas e gerentes distritais), e que se sentiu muito confortável e confiante nestas etapas, pelo real preparo dos gestores. Já no segundo caso, a impressão foi totalmente contrária, justificada por uma condução superficial do recrutador, que não o questionou sobre aspectos pessoais, como propósito e valores. Apesar de ter se sentido reprimido e chateado com o acontecido, conta que aceitou a proposta para a vaga, visto que queria muito retornar à empresa, pela lembrança de todas as experiências positivas prévias de desenvolvimento e reconhecimento.

Quadro 3 - Síntese dos relatos - Durante o Processo Seletivo

\begin{tabular}{|l|l|}
\hline GJ & $\begin{array}{l}\text { Apesar das sensações positivas com a oportunidade da vaga, o processo de entrevistas não causou boa } \\
\text { impressão por conta do total despreparo e insensibilidade do entrevistador, que gerou grande incômodo ao } \\
\text { dizer que não havia possibilidade de efetivação. }\end{array}$ \\
\hline GSM & $\begin{array}{l}\text { Experiência muito gratificante, respeitosa e transparente. Passou por entrevistas com a área de Recrutamento e } \\
\text { Seleção e os Diretores Médicos da área em que iria trabalhar, e se sentiu muito engajada com a cultura da } \\
\text { organização e motivada a continuar a competir pela vaga. }\end{array}$ \\
\hline GDM & $\begin{array}{l}\text { Contatada por headhunters para conversar sobre sua trajetória profissional e entender seus anseios de carreira. } \\
\text { Também entrevistada pelos dois presidentes da época, que foram muito receptivos, abertos e a conquistaram } \\
\text { para que aceitasse a proposta. }\end{array}$ \\
\hline GFV & $\begin{array}{l}\text { Passou por dois processos seletivos: o primeiro para uma vaga de estágio e o último, em 2017, para uma posição } \\
\text { efetiva. A primeira experiência de entrevistas foi positiva, confortável e confiante. Já na segunda, a impressão } \\
\text { foi totalmente contrária, pois o processo foi conduzido de maneira superficial e o recrutador não o questionou } \\
\text { sobre aspectos pessoais, como propósito e valores. }\end{array}$ \\
\hline
\end{tabular}

Fonte: Elaborado pelas autoras (2021).

Foi possível compreender que as impressões sobre o processo seletivo foram distintas e pautadas na experiência de cada um, bem como na interface com os stakeholders envolvidos. Nesse sentido, foram compartilhadas tanto experiências positivas e que impulsionaram o engajamento deles com a empresa, como, por outro lado, em alguns casos, houve falha de comunicação e baixa empatia com o candidato, causando descontentamento por parte dos entrevistados. Analisando isso, é interessante observar que com 
experiências positivas ou negativas, independentemente, os candidatos se mantiveram ativos no processo devido ao interesse e à identificação com a empresa, sua marca e proposta de valor. Este fato reforça o que Reis e Braga (2016) afirmam, de que o Employer Branding visa desenvolver uma relação de lealdade com o público-alvo da organização, reforçando atributos exclusivos e atraentes que podem ser oferecidos aos seus colaboradores. Isso faz com que o valor da marca seja um peso essencial para a influência e a tomada de decisão dos candidatos. Apesar disso, diante do notável papel estratégico da área de Recursos Humanos nesse primeiro contato com o candidato, um indício de alerta pôde ser verificado, indicando eventuais pontos de melhoria nesse momento, a fim de melhorar a jornada de experiência.

\subsection{Ingresso na organização}

Na terceira etapa de entrevistas, buscou-se apreender a satisfação dos entrevistados em relação ao seu ingresso na organização, através do processo de on-boarding.

O GJ relatou uma experiência boa, lembrando que ficou muito contente por perceber a preocupação que a empresa tinha com a recepção e a integração dos novos colaboradores, abordando temas como negócio da empresa, principais departamentos, cenário de mercado, entre outros aspectos relacionados. Apesar de ter sido positivo, o gestor menciona que o on-boarding que é aplicado mais atualmente na organização ainda carece de melhorias, ressaltando a necessidade deste processo ser mais contínuo e estruturado, visto que os negócios da empresa estão se tornando cada vez mais complexos. Mesmo assim, uma vantagem mencionada por ele diz respeito à integração mais completa e detalhada que o gestor faz com os novos ingressantes sobre sua área em específico, também apresentando características e peculiaridades da empresa nesse sentido.

A GSM também teve uma impressão positiva sobre seu on-boarding, sentindo-se muito confortável durante o processo, relatando ter sido bem recebida pelos membros do time, que estavam dispostos a ajudá-la e a compartilhar sobre o dia a dia, cultura, desafios da área, entre outros. Ela ressaltou que logo que foi admitida, foi disparado um e-mail sobre sua chegada para toda a organização, contando sobre sua história profissional. Isso a fez se sentir acolhida e bastante reconhecida, além de tê-la emocionado muito.

O processo da GMD foi bastante atípico, totalmente acompanhado pela alta liderança da empresa, com os presidentes e diretores financeiros, fornecendo suporte e conhecimento. Ela caracterizou o onboarding como "fenomenal". Apesar de toda a ajuda que teve durante seu início, também optou por buscar informações por si só, o que a fez expandir mais ainda seu conhecimento sobre a área e desafios com que iria se deparar. Também disse ter tido ótimas impressões sobre como os grandes líderes lidam com o fator humano dentro da organização.

Já a experiência do GFV foi bastante diferente, até por ter passado por dois processos distintos, em momentos diferentes. Na primeira experiência, como estagiário, não houve processo de integração, o que causou um sentimento de não pertencimento. Já a segunda, mais recente, teve, mas voltado a assuntos administrativos, como admissão, ferramentas de trabalho e benefícios, não fomentando temas como cultura organizacional, missão e valores da organização, modelo de trabalho, entre outros aspectos. Apesar disso, mencionou que neste momento, a empresa vinha passando por um momento de transformação cultural muito grande, e, por isso, acredita que atualmente o processo esteja mais estruturado.

Quadro 4 - Síntese dos relatos - Ingresso na Organização

\begin{tabular}{|l|l|}
\hline GJ & $\begin{array}{l}\text { Experiência positiva por reconhecer preocupação que a empresa tinha com a recepção e integração dos novos } \\
\text { funcionários. Apesar disso, ressaltou necessidade do processo atual ser mais contínuo e melhor estruturado, } \\
\text { visto que os negócios da empresa ficam cada vez mais complexos. }\end{array}$ \\
\hline GSM & $\begin{array}{l}\text { Impressão positiva, sentindo-se confortável e bem recebida por todos da área, que estavam dispostos a ajudá- } \\
\text { la e a contar sobre o dia a dia, cultura etc. }\end{array}$ \\
\hline GDM & $\begin{array}{l}\text { Processo de integração atípico, acompanhado pela alta liderança, que forneceram suporte e conhecimento. } \\
\text { Descreveu como "fenomenal", com ótimas impressões sobre a liderança da empresa. }\end{array}$ \\
\hline GFV & $\begin{array}{l}\text { Duas experiências. Na primeira, como estagiário, não houve processo de integração, o que o deixou um pouco } \\
\text { perdido. Na segunda, mais recente, participou de uma integração, mas com foco no administrativo, e não na } \\
\text { cultura e valores da empresa. }\end{array}$ \\
\hline
\end{tabular}

Fonte: Elaborado pelas autoras (2021). 
Em grande parte, a experiência com o on-boarding na empresa foi positiva, gerando sentimento de pertencimento e integrando os novos colaboradores. Entretanto, apesar da existência de um processo de integração, alguns dos gestores entrevistados evidenciaram a necessidade de uma maior imersão no negócio, sua cultura e valores. Uma sugestão apresentada seria o desenvolvimento de um on-boarding contínuo, durante um período específico, como o primeiro ano dos funcionários na empresa. Tal apontamento vem em concordância com Cable, Gino e Staats (2013), que defendem a importância de fazer com que os funcionários entendam e se comprometam com os valores da organização em seu primeiro dia, promovendo uma real imersão, bem como gerando senso de pertencimento e de orgulho em fazer parte do time.

\subsection{Permanência e Experiências na organização}

O objetivo desta etapa foi verificar a avaliação dos entrevistados em relação às suas experiências dentro da empresa, na tentativa de retratar um cenário de trabalho atual.

O GJ se mostrou bastante motivado em responder esta pergunta e comentar sobre os importantes feitos realizados por ele e sua equipe no que se refere ao engajamento da área jurídica com os outros departamentos da empresa. Acontece que ela sempre foi vista como "vilã", por estar associada à burocracia; mas, após um trabalho árduo de mudança de mindset realizado por eles, o reconhecimento da área é hoje totalmente diferente, sendo vista como uma verdadeira parceira do negócio, sempre disposta e apta a solucionar os problemas mais complexos. Ele comentou que a cultura da empresa ajudou bastante nesse processo de mudança, pois possui um time de liderança, principalmente na diretoria, que acredita muito no potencial de seus colaboradores e os incentivam com os pilares da cultura "Unboss", que envolve a problemática da desierarquização. Por conta disso, ele se sente realizado e feliz com as conquistas, bem como com o cenário atual de sua área, o que o motiva a trabalhar diariamente. Apesar disso, ele também relatou que, ainda que a empresa possua estrutura e materiais que possibilitem o desenvolvimento dos funcionários, estes acabam não encontrando tempo para utilizá-los da melhor maneira. Também relatou que os colaboradores se esforçam para realizar os treinamentos, mas muito mais como cumprimento de metas e desafios, do que com o foco na qualidade. Diante disso, o gestor idealiza que seria importante ter incentivos de aprendizado em menos quantidade, mas com mais qualidade e foco no objetivo de desenvolvimento de cada pessoa.

A GSM mencionou que a empresa possui um grupo de liderança muito forte e que lida com transparência em suas ações, o que torna a cultura e o trabalho de todos totalmente congruente. Além disso, comentou que sente que está em uma organização que busca por novas formas de inovar com seus colaboradores e clientes. Como exemplo, tem-se a sua própria área, o SIC (Serviço de Informação ao Cidadão), que anteriormente era administrado pelo jurídico, mas hoje tem um time focado apenas no relacionamento com o cliente, o que evidencia a importância dada. De maneira similar, ela concorda que existe um espaço de melhoria muito grande na empresa, visto que muitas plataformas de desenvolvimento são oferecidas aos colaboradores, mas sente que este excesso acaba fazendo com que perca o significado. Outro ponto mencionado foram as pesquisas de satisfação, que, segundo ela, pelos colaboradores não entenderem a importância e relevância disso para a organização, acabam respondendo com vieses ou de maneira rasa. Por isso, existe necessidade de comunicação mais informativa aos funcionários, explicitando os objetivos esperados e posteriores ações relacionadas.

A fala da GDM foi bem parecida às anteriores. Ela também se sente bem em relação a sua situação de trabalho, relatando que nos quesitos liderança e cultura a empresa é bem estruturada e consegue transparecer isso aos seus colaboradores. Apesar disso, para ela, ainda existem gaps quanto à hierarquização: mesmo sendo um ponto que a empresa vem trabalhando para desenvolver, como com o projeto "unboss", ainda é algo aparente nas áreas. Ela também relata a necessidade de comunicação mais informativa aos funcionários, que ainda não entendem claramente a "desierarquização". A gestora também reconhece que a empresa fornece boas ferramentas para o desenvolvimento de todos, porém não é algo guiado, sendo insuficiente na instrução de um caminho a ser seguido para utilização destes recursos de aprendizado. Além disso, ela comentou sobre altos investimentos feitos em cursos não tão interessantes aos funcionários, perdendo a oportunidade estratégica de focar em temas mais atrativos e pertinentes.

A impressão do GFV também se mostrou positiva, com ele se sentindo à vontade para expressar sua opinião e recebendo incentivo de seu time e gestores para ter uma comunicação transparente. Também ressaltou que não sente a preocupação e o medo de levar algum feedback para seus superiores diretores, mas pelo contrário, sente-se engajado a fazê-lo. Ele repetiu a opinião da GSM sobre as pesquisas de satisfação, 
relatando que, apesar de enxergar o incentivo da empresa e os gestores, sente que os colaboradores acabam não dando valor para isso e respondem apenas "por responder". O entendimento dele acerca deste baixo engajamento é de que os colaboradores acreditam que tais pesquisas funcionam apenas como ferramenta de mercado e fortalecimento de marca, e não para uma real avaliação de satisfação do corpo de funcionários e busca por melhorias internas. Em relação aos diferenciais e pontos mais valorizados na empresa, ele mencionou o poder de engajar seus funcionários em sua causa, de "transformar vidas", comentando que se emociona ao falar sobre este propósito. Além disso, também a questão do incentivo ao desenvolvimento e à satisfação dos colaboradores de uma forma geral foi mencionada.

\section{Quadro 5 - Síntese dos relatos - Permanência e Experiências na Organização}

\begin{tabular}{|c|l|}
\hline GJ & $\begin{array}{l}\text { Sente-se motivado e reconhecido, bem como realizado e feliz. Ressalta a cultura da empresa, especialmente } \\
\text { em relação à liderança e o pilar "unboss". Apesar da estruturação da empresa possibilitar o desenvolvimento } \\
\text { dos funcionários, isso não acontece de maneira satisfatória: seja pela falta de tempo, ou visão de cumprimento } \\
\text { de desafio, apenas. Por isso ressalta que os incentivos de aprendizagem deveriam focar na qualidade. }\end{array}$ \\
\hline GSM & $\begin{array}{l}\text { Acredita que a empresa possui um grupo de liderança muito bom e que lida com transparência em suas ações, } \\
\text { o que torna a cultura e o trabalho de todos totalmente congruente. Além disso, sente - se que está em uma } \\
\text { organização que busca por novas formas de inovar com seus colaboradores e clientes. Mas ainda existe um } \\
\text { espaço de melhoria na gestão de desenvolvimento através das plataformas oferecidas. }\end{array}$ \\
\hline GDM & $\begin{array}{l}\text { Sente-se bem em relação a sua situação de trabalho e que no quesito liderança e cultura, a empresa é super } \\
\text { bem estruturada e consegue transparecer isso aos colaboradores, mas que ainda existem GAPS quanto à } \\
\text { hierarquização. Além disso, reconhece que a empresa possui boas ferramentas para o desenvolvimento de } \\
\text { todos, porém não é algo guiado e falta traçar um caminho a ser seguido para utilização destes recursos de } \\
\text { aprendizado. }\end{array}$ \\
\hline GFV & $\begin{array}{l}\text { Comentou que se sente muito à vontade para expressar sua opinião e recebe muito incentivo de seu time e } \\
\text { gestores para ter uma comunicação transparente, bem como, não sente a preocupação e o medo de levar algum } \\
\text { ponto, feedback para seus chefes e diretores, mas pelo contrário, se sente engajado a fazê-lo. }\end{array}$ \\
\hline
\end{tabular}

Fonte: Elaborado pelas autoras (2021).

De forma geral, todos os gestores indicaram boas avaliações sobre suas situações de trabalho, especialmente referente à cultura da organização e ao incentivo ao desenvolvimento e aprendizado dos colaboradores. Conforme explanado no referencial, tais fatores contribuem para gerar maior engajamento de atuais e futuros empregados com a estratégia da empresa, segundo Reis e Braga (2016). Além disso, ficou evidente a importância de oferecimento de melhorias de carreira e desenvolvimento por parte da empresa, ponto fundamental no reconhecimento dos esforços dos funcionários, bem como no atingimento de metas e objetivos, como afirmam Ahmad e Daud (2016). Apesar disso, algumas críticas foram tecidas nesse sentido, tais como a falta de apoio na estruturação do aprendizado do colaborador e a necessidade de uma comunicação mais informativa por parte da gestão de pessoas, a fim de esclarecer pontos importantes, como o pilar "unboss" e as pesquisas de satisfação. Tais resultados se mostram consonantes com o defendido por Mascarenhas (2017), quando afirma que a soma das vivências do empregado em todas as dimensões do dia a dia na empresa - do ambiente físico de trabalho à forma como ele se relaciona e é avaliado - é que constrói a marca empregadora.

\subsection{Entendimento sobre o que é o Employer Branding}

A quinta e última etapa de entrevistas visou captar o entendimento dos gestores entrevistados acerca da temática de Employer Branding ou Marca Empregadora, inclusive referente à visão deles sobre as práticas disso na empresa em estudo.

O GJ nunca havia ouvido falar sobre Employer Branding, mas acredita que sejam ações estabelecidas e aplicadas dentro da empresa para que a marca fique cada vez mais em evidência. Além disso, percebe que não há uma área estruturada para isso dentro da empresa atualmente, mas que talvez o RH seja - melhor departamento para realizar este trabalho, visto o conhecimento sobre a percepção dos colaboradores, bem como dos diferenciais da empresa e suas oportunidades de desenvolvimento do corpo de funcionários. 
Em contrapartida, a GM comentou que já havia escutado sobre o termo, pois tem uma colega que lidera projetos nesse sentido em outra organização, trabalhando sempre com stakeholders internos e externos. Ela também ressaltou a inexistência de uma área focada nisso, mas, por outro lado, a existência de ações de fortalecimento de marca. Por isso, ela ressaltou o desafio de uma estruturação mais estratégica e eficaz, indicando ainda como parâmetro as empresas de bens de consumo.

A GMD já estava mais interada quanto ao tema, principalmente devido às reuniões executivas, onde questões como programas de people management e engajamento dos colaboradores com a organização estão em alta. Em igual sentido, também ressaltou a necessidade de uma estrutura interna dedicada apenas ao fortalecimento de marca empregadora, tanto interna quanto externamente. Novamente as empresas de bens de consumo foram citadas como parâmetro, justificada pela exigência do mercado.

Voltando ao não conhecimento, o GFV também nunca ouviu falar sobre o termo, bem como não imagina como é o funcionamento da área. Mais incisivo, ele afirmou que não ficam evidentes as práticas de gestão de marca empregadora na empresa, além da prática atual não ser divulgada ao público externo de maneira clara e eficiente, diminuindo a visibilidade no mercado. Apesar disso, menciona que para os profissionais já inseridos na indústria farmacêutica, a empresa é muito atrativa e de interesse dos candidatos.

\section{Quadro 6 - Síntese dos relatos - Entendimento sobre o Employer Branding}

\begin{tabular}{|c|l|}
\hline GJ & $\begin{array}{l}\text { Sem conhecimento prévio, mas acredita que sejam ações estabelecidas e aplicadas dentro da empresa para que } \\
\text { a marca fique cada vez mais em evidência. Não percebe área estruturada para isso, mas acredita que o RH seja } \\
\text { o melhor departamento para realizar este trabalho. }\end{array}$ \\
\hline GSM & $\begin{array}{l}\text { Conhecimento devido à colega que lidera um projeto de marca empregadora em outra empresa. Reconhece } \\
\text { ações de nesse sentido, mas também não percebe área estruturada para isso. Menciona desafio de estruturação } \\
\text { mais estratégica e eficaz, ilustrando-o com as empresas de bens de consumo. }\end{array}$ \\
\hline GDM & $\begin{array}{l}\text { Conhecimento devido à participação em reuniões executivas, abordando temas de people management e } \\
\text { desenvolvimento dos colaboradores. Também não percebe área dedicada a isso, ressaltando a necessidade de } \\
\text { estruturação interna. Também mencionou as empresas de bens de consumo nesse sentido. }\end{array}$ \\
\hline GFV & $\begin{array}{l}\text { Sem nenhum conhecimento prévio, tampouco visualiza tais práticas na empresa, mencionando ainda a } \\
\text { inexistência de divulgação externa. Apesar disso, ressaltou que a marca é forte para profissionais já estão } \\
\text { inseridos na indústria farmacêutica. }\end{array}$ \\
\hline
\end{tabular}

Fonte: Elaborado pelas autoras (2021).

Assim, pôde-se observar que a temática ainda é pouco conhecida e difundida no mercado, exceto para os profissionais que já trabalham em áreas diretamente correlacionadas, corroborando o salientado por Oltramari, Córdova e Tonelli (2019). Além disso, ficou perceptível a necessidade de uma melhor estruturação da marca empregadora na empresa, com a centralização de esforços em um departamento específico. Somente assim os benefícios de tais práticas serão conseguidos, com a real internalização, bem como consequentemente repercutidos no mercado.

\section{CONSIDERAÇÕES FINAIS}

O trabalho teve como objetivo analisar a compreensão e a utilização do Employer Branding em uma organização multinacional do ramo farmacêutico. Para tanto, realizou-se um estudo de caso, com triangulação de dados: apresentação e caracterização da empresa, amparada na observação participante da pesquisadora como membro integrante dela, e aplicação de entrevistas semiestruturadas junto a quatro gestores de áreas distintas. Com isso, foi possível verificar tanto como e quais as estratégias da marca empregadora são aplicadas na empresa, quanto, mais importante, como são percebidas pelos seus colaboradores, tanto de maneira implícita quanto explicitamente.

A empresa multinacional em estudo é do ramo farmacêutico e vem construindo uma história de mais de 250 anos com base no desenvolvimento de produtos inovadores que trazem benefícios à saúde e ao progresso humano. Com unidades administrativas e fabris no Brasil, a estratégia da organização é trabalhar com a inovação, baseada na ciência, para proporcionar os melhores resultados aos pacientes, desde a melhora do custo-efetividade de um medicamento, da alta qualidade nos cuidados oferecidos, até o prolongamento da vida. 
Com a análise das entrevistas realizadas, interessantes insights foram identificados sobre a gestão de marca empregadora na organização em estudo, enfatizando a importância das estratégias de Employer Branding através de forte e atrativo posicionamento no mercado de trabalho, bem como no desenvolvimento, oportunidades de crescimento e engajamento de seus talentos internos, cultuando um bom ambiente de trabalho que incentive potenciais produtivos e criativos. Além disso, é evidente que o papel da liderança da organização é o de disseminar os valores da mesma e atuar com transparência na comunicação com os seus colaboradores, para que se sintam representados e parte do negócio.

Levando em consideração que o processo de atração de talentos é estratégico e que a experiência do colaborador é fundamental para fortalecimento de uma marca empregadora, o investimento em Employer Branding se mostrou fundamental para que os empregados se sintam satisfeitos com o ambiente, cultura, valores e oportunidades de desenvolvimento em uma organização e disseminem este sentimento para o mercado de maneira genuína. Afinal, são essas estratégias que constroem um ambiente de trabalho melhor, mais acolhedor e que se destaca perante à concorrência, contribuindo com a consolidação de uma marca forte no mercado. Sendo assim, como contribuição gerencial, evidencia-se a marca empregadora como imprescindível na atuação estratégia organizacional, em especial em relação ao diferencial competitivo relativo ao gerenciamento dos funcionários.

Apesar do Employer Branding ser um tema pouco abordado em estudos acadêmicos, a contribuição teórica desta pesquisa foi fundamental para o embasamento e desenvolvimento dela. Em todos os artigos analisados se evidencia a importância que as empresas têm dado para estruturar sua marca empregadora, atraindo, desenvolvendo e retendo talentos. Neste sentido, os artigos teóricos mencionados no estudo contribuíram na compreensão da aplicação e importância das estratégias de Employer Branding nas organizações, visando uma melhor experiência do candidato e colaborador.

Apesar dos resultados obtidos, deve-se pontuar algumas limitações do estudo. A primeira delas diz respeito à delimitação da empresa e dos sujeitos de pesquisa, refletindo em opiniões pessoais e individuais que não podem ser generalizadas e definidas como únicas. Já a segunda implicação se refere ao método de coleta de dados por entrevista, que pode gerar vieses e questionamentos por parte dos entrevistados, mesmo com toda a contextualização sobre o projeto. Em terceiro, pontua-se que a pesquisadora também faz parte da organização, o que pode, de certa forma, ter inibido declarações mais sinceras e incisivas.

Por fim, como sugestões de estudos futuros, faz-se notória a necessidade de maiores estudos na área e implementação das técnicas de Gestão de Marca Empregadora, de forma a proporcionar análises mais concisas e que beneficiem as organizações. Além disso, também se sugere a realização de estudos que tenham como premissa a visão e opinião de colaboradores de empresas de diversos segmentos sobre suas experiências com o Employer Branding, bem como, análise da impressão de profissionais atuantes na área, compreendendo desafios e pontos de melhoria.

\section{REFERÊNCIAS}

AHMAD, Nor Adibah; DAUD, Salina. Engaging people with employer branding. Procedia Economics and Finance, v. 35, p. 690-698, 2016.

ALTON, L. How Millennials Are Reshaping What's Important In Corporate. 2017. Disponível em: https://www.forbes.com/sites/larryalton/2017/06/20/how-millennials-are-reshaping-whats-important-incorporate-culture/\#7d0eff6e2dfb. Acesso em: 26 out. 2020.

AMBLER, T.; BARROW, S. The employer brand. Journal of Brand Management, v. 4, p. 185-206, dez. 1996.

BACKHAUS, K.; TIKOO, S. Conceptualizing and researching employer branding. New York: Career Development International, 2004.

BANTA, K.; WATRAS, M. Why We Need to Rethink “Employer Brand”. Harvard Business Review. Jun. 2019. Disponível em: https://hbr.org/2019/06/why-we-need-to-rethink-employer-brand. Acesso em: 25 set. 2020.

BLACK, J. Stewart; MANOHAR, Manjith; STEHLI, Susan. The war for leadership talent: Creating a superior employee value proposition. Lausanne, Switzerland: International Institute of Management Development, 2013.

CABLE, Daniel M.; GINO, Francesca; STAATS, Bradley R. Reinventing employee onboarding. MIT Sloan Management Review, v. 54, n. 3, p. 23-28, 2013. 
DABIRIAN, A.; KIETZMANN, J.; DIBA, H. A great place to work!? Understanding crowdsourced employer branding. Estados Unidos: Business Horizons, 2017. 9 p.

GILLIVER, S. Badenoch \& Clark guide. Employer Branding Essentials, v. 4, n. 3, p. 35-50, 2009.

GOSWAMI, Shivani; AGARWAL, Rahul. A Study on Employer Branding and Its Impacts on Employee's Attraction and Retention. International Journal of Management and Social Sciences Research, v. 4, n. 6, p. 9-15, 2015.

HADI, N. U.; AHMED S. Role of Employer Branding Dimensions on Employee Retention: Evidence from Educational Sector. Administrative Sciences, v. 8, n. 44, p. 1-15, 2018.

HEGER, Brian K. Linking the employment value proposition (EVP) to employee engagement and business outcomes: Preliminary findings from a linkage research pilot study. Organization Development Journal, v. 25, n. 2, p. 121-132, 2007.

HOLLIDAY, K. Putting brands to test. U.S. Banker, v. 107, n. 12, p. 58-60, 1997.

KUSCE, A.; OKAN, E. An Exploratory Study on the Dimensions of Employer Branding. Öneri Dergisi, v. 9, n. 34, p. 119-130, 2010.

MANZINI, Eduardo José. A entrevista na pesquisa social. Didática, v. 26, p. 149-158, 1990.

MASCARENHAS, Bruna Gomes. Employer branding no ciclo de relacionamento com empregados. Comunicação com líderes e empregados, v. 3, p. 103-108, 2017.

MAXWELL, Joseph A. Qualitative research design: an interactive approach. USA: Sage publications, 2012.

OLTRAMARI, Andrea Poleto; CÓRDOVA, Rosana; TONELLI, Maria José. Trabalhador-consumidor: a atração de jovens pelo employer branding na escolha profissional. Cadernos EBAPE. BR, v. 17, n. espec., p. 750764, 2019.

REIS, Germano Glufke; BRAGA, Beatriz Maria. Employer attractiveness from a generational perspective: Implications for employer branding. Revista de Administração, São Paulo, v. 51, n. 1, p. 103-116, 2016.

STAKE, R. E. Qualitative Case Studies. In:DENZIN, N. K.; LINCOLN, Y. S. (ed.). he Sage handbook of qualitative research. USA: Sage Publications Ltd, 2005. p. 443-466.

TAYLOR, S. Resourcing and Talent Management. 5. ed. London: Chartered Institute of Personnel and Development, 2010.

VELOSO, I. Qual é o seu employer brand? o papel da marca na guerra do talento e na estratégia das empresas. 1. ed. Lisboa: Conjuntura Actual Editora, 2018.156 p.

VERGARA, R. G. Um Estudo Exploratório sobre a Employee Value Proposition (EVP) no Mercado de Seguros Brasileiro. 2016. 87 f. Dissertação de mestrado em (Administração de Empresas) - Escola de Administração de Empresas de São Paulo da Fundação Getúlio Vargas, São Paulo, 2016.

VERGARA, S. C. Projetos e Relatórios de Pesquisa em Administração. 14. ed. São Paulo: Editora Atlas, 2013. 94 p.

WAHBA, M; ELMANADILY, D. Employer Branding Impact on Employee Behavior and Attitudes Applied Study on Pharmatecual in Egypt. International Journal of Management and Sustainability, v. 4, n. 6, 145-162, 2015. DOI 0.18488/journal.11/2015.4.6/11.6.145.162.

WATSON, Gillian; REISSNER, Stefanie (Ed.). Developing skills for business leadership. USA: Kogan Page Publishers, 2014. 